Article

\title{
Silylation of Dinitrogen Catalyzed by Hydridodinitrogentris(Triphenylphosphine)Cobalt(I)
}

\author{
Wojciech I. Dzik
}

Van't Hoff Institute for Molecular Sciences (HIMS), Homogeneous, Supramolecular and Bio-Inspired Catalysis, Universiteit van Amsterdam, P.O. Box 94720, 1090 GS Amsterdam, The Netherlands; w.i.dzik@uva.nl; Tel.: +31-20-525-7208

Academic Editors: Duncan H. Gregory and Gianfranco Pacchioni

Received: 14 April 2016; Accepted: 28 June 2016; Published: 5 July 2016

\begin{abstract}
Recently, homogeneous cobalt systems were reported to catalyze the reductive silylation of dinitrogen. In this study the investigations on the silylation of dinitrogen catalyzed by $\mathrm{CoH}\left(\mathrm{PPh}_{3}\right)_{3} \mathrm{~N}_{2}$ are presented. We show that in the presence of the title compound, the reaction of $\mathrm{N}_{2}$ with trimethylsilylchloride and sodium yields, on average, 6.7 equivalents of tris(trimethylsilyl)amine per Co atom in THF (tetrahydrofuran). The aim was to elucidate whether the active catalyst is: (a) the $\left[\mathrm{Co}\left(\mathrm{PPh}_{3}\right)_{3} \mathrm{~N}_{2}\right]^{-}$anion formed after two-electron reduction of the title compound; or (b) a species formed via decomposition of $\mathrm{CoH}\left(\mathrm{PPh}_{3}\right)_{3} \mathrm{~N}_{2}$ in the presence of the highly reactive substrates. Time profile, and IR and EPR spectroscopic investigations show instability of the pre-catalyst under the applied conditions which suggests that the catalytically active species is formed through in situ modification of the pre-catalyst.
\end{abstract}

Keywords: nitrogen activation; silylamines; cobalt; homogeneous catalysis

\section{Introduction}

Effective catalytic activation of dinitrogen under ambient conditions remains one of the biggest challenges in synthetic chemistry. Although such a transformation is feasible, as evidenced by the biosynthesis of ammonia enabled by nitrogenase enzymes [1-4], the activation of dinitrogen on transition metal complexes is not trivial and the best man-made homogeneous catalysts for ammonia synthesis can perform only several dozens of catalytic turnovers [5-13].

In this context, most of the effort has been focused on molybdenum and iron systems [14-18]. Two major strategies for catalytic $\mathrm{N}_{2}$ activation by homogeneous systems were developed: reductive protonation to yield ammonia and reductive silylation to yield silylamines (Figure 1).

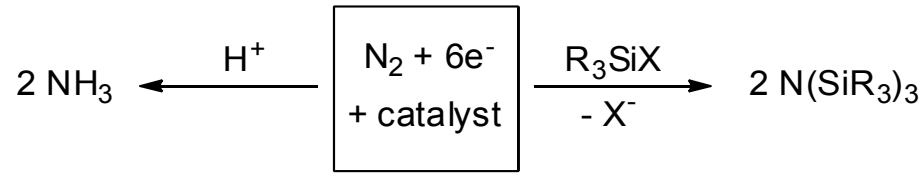

Figure 1. Strategies for catalytic reduction of $\mathrm{N}_{2}$ at ambient conditions.

Catalytic formation of ammonia on well-defined systems was pioneered by the group of Schrock who developed a molybdenum-based system that catalyzed the formation of almost eight equivalents of $\mathrm{NH}_{3}$ per metal atom [19]. The group of Nishibayashi developed binuclear catalysts which were able to catalyze the formation of up to 63 equivalents of $\mathrm{NH}_{3}$ per Mo atom [20,21]. Iron also proved to be catalytically active as shown by the group of Peters, whose catalysts could produce up to 64 equivalents of $\mathrm{NH}_{3}$ at very low temperatures [22,23]. 
However, these catalysts suffer from poisoning with ammonia and dihydrogen formed as side products. This is usually not the case in catalytic silylation reactions and therefore this reaction generally yields more turnovers of $\mathrm{N}_{2}$ fixation (Figure 2). Catalytic reductive silylation of $\mathrm{N}_{2}$ was pioneered by Shiina who used $\mathrm{CrCl}_{3}$ as the pre-catalyst. This led to formation of 5.4 equivalents of $\mathrm{N}\left(\mathrm{SiMe}_{3}\right)_{3}$ when $\mathrm{N}_{2}$ was reacted with lithium and $\mathrm{Me}_{3} \mathrm{SiCl}$ [24]. Other salts of various metals yielded much less of the desired product. For instance, the use of $\mathrm{CoCl}_{2}$ which is relevant to the research presented here led to the formation of 1.2 equivalents of $\mathrm{N}\left(\mathrm{SiMe}_{3}\right)_{3}$ per metal centre. This chemistry was further developed for well-defined Mo and W systems by the groups of Hidai [25] and Nishibayashi [26]. Another well-defined molybdenum catalyst was recently disclosed by Mézailles and co-workers [27]. The group of Nishibayashi also reported that simple organometallic iron compounds can be used as pre-catalysts in this reaction and up to 34 equivalents of $\mathrm{N}\left(\mathrm{SiMe}_{3}\right)_{3}$ could be formed when a ferrocene derivative was used [28]. Interestingly, none of the studied iron compounds contain coordinated dinitrogen, and an approximately $1 \mathrm{~h}$ incubation period was observed, indicating that the catalytically active species is formed by reaction of the iron pre-catalyst with silylchlorides under reductive conditions. A two-coordinate iron(0) complex supported with a cyclic (alkyl)(amino)carbene ligand which revealed comparable activity was recently reported by Ung and Peters [29].

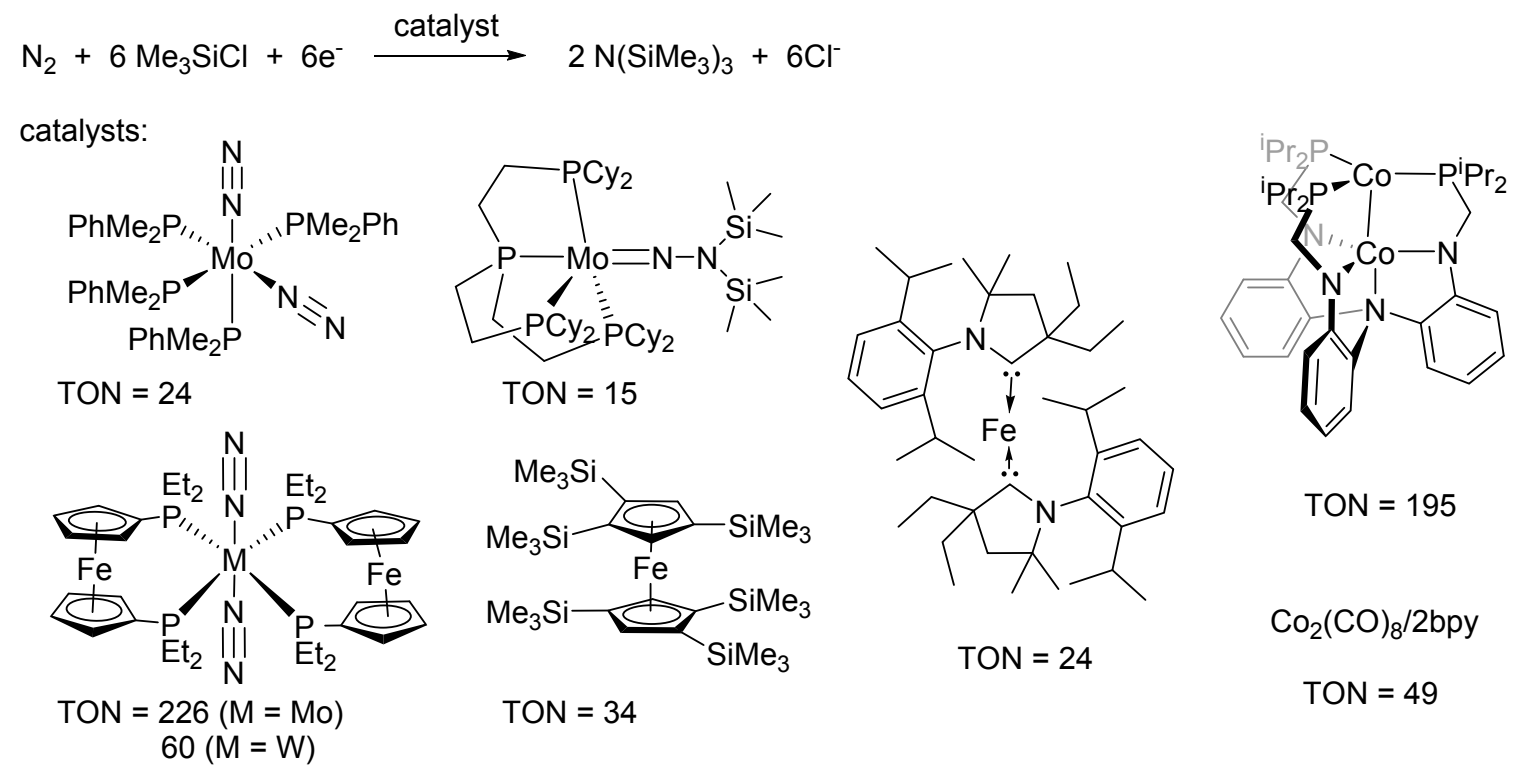

Figure 2. Selected (pre)catalysts for reductive trimethylsilylation of dinitrogen.

Despite the fact that cobalt-containing catalysts [30] are active in the Haber-Bosch reaction, only a handful of homogeneous systems based on this metal have been reported in the context of $\mathrm{N}_{2}$ activation. Yamamoto and co-workers showed that treatment of $\left\{\left[\mathrm{Co}\left(\mathrm{PPh}_{3}\right)_{3} \mathrm{~N}_{2}\right]^{-}\right\}_{x} \mathrm{M}^{x+}(\mathrm{THF})_{2+x}(\mathrm{M}=\mathrm{Li}, \mathrm{Na}$, $\mathrm{Mg}$ ) complexes with acids leads to the formation of ammonia and hydrazine in sub-stoichiometric quantities [31]. Peters and co-workers reported methylation and trimethylsilylation of dinitrogen bound to $\left[\left(\mathrm{PhB}\left(\mathrm{CH}_{2} \mathrm{P}^{i} \mathrm{Pr}_{2}\right)_{3}\right) \mathrm{CoN}_{2}\right]_{2} \mathrm{Mg}(\mathrm{THF})_{4}$ (Figure 3) [32]. Last year, Gagliardi, Lu and co-workers reported a dinuclear cobalt complex that catalyzes the formation of $\mathrm{N}\left(\mathrm{SiMe}_{3}\right)_{3}$ from dinitrogen with an impressive turnover number of 195 [33], while the group of Nishibayashi showed that in the presence of 2-2'-bipyridine, $\mathrm{Co}_{2}(\mathrm{CO})_{8}$ can catalyze the formation of up to 49 equivalents of $\mathrm{N}\left(\mathrm{SiMe}_{3}\right)_{3}$ (Figure 2) [34]. Homogeneous cobalt complexes with tris(phosphine)borate ligands were also shown by Peters and co-workers to catalyze the formation of over two equivalents of ammonia [35]. 


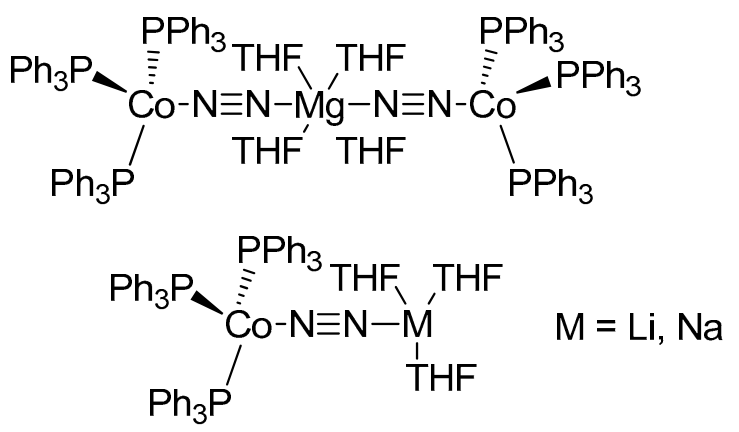

Yamamoto et al.

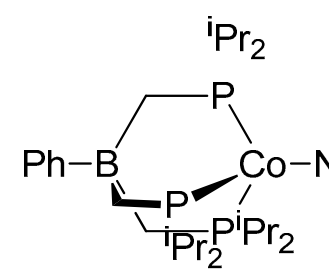

Peters et al.

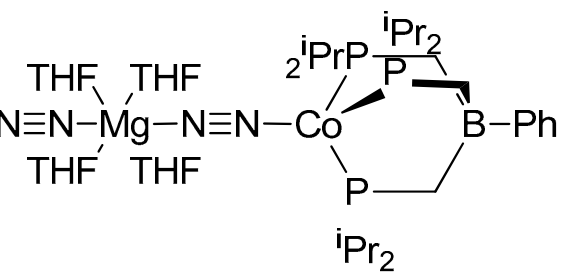

i $\mathrm{Pr}_{2}$

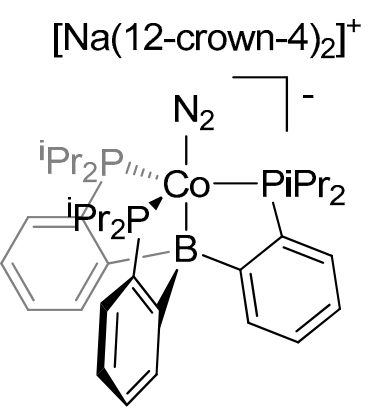

Peters et al.

Figure 3. Cobalt dinitrogen complexes that allow reactivity of coordinated $\mathrm{N}_{2}[31,32,35]$.

\section{Results and Discussion}

Since Yamamoto's [Co $\left.\left(\mathrm{PPh}_{3}\right)_{3} \mathrm{~N}_{2}\right]^{-}$complex promoted the reduction of the coordinated $\mathrm{N}_{2}$ in THF to ammonia and hydrazine, it seemed plausible that it could also promote the silylation of dinitrogen. Indeed, recently the group of Nishibayashi mentioned that $\mathrm{CoH}\left(\mathrm{PPh}_{3}\right)_{3} \mathrm{~N}_{2}$ catalyzes the reductive silylation of $\mathrm{N}_{2}$ [34]. Given the fact that $\left[\mathrm{Co}\left(\mathrm{PPh}_{3}\right)_{3} \mathrm{~N}_{2}\right]^{-}$can be formed, e.g., by the reduction of $\mathrm{CoH}\left(\mathrm{PPh}_{3}\right)_{3} \mathrm{~N}_{2}$ with alkali metals, we decided to investigate the activity of the cobalt triphenylphosphine system in silylation of $\mathrm{N}_{2}$ in more detail.

One could expect that $\left[\mathrm{CoN}_{2}\left(\mathrm{PPh}_{3}\right)_{3}\right]^{-}$should directly react with $\mathrm{Me}_{3} \mathrm{SiCl}$, resulting in the formation of $\mathrm{Si}-\mathrm{N}$ bonds, similarly to the dinuclear system reported by the groups of Gagliardi and $\mathrm{Lu}$ [33]. However, as shown by Nishibayashi, Yoshizawa and co-workers, many simple cobalt complexes reveal long incubation periods before the onset of the catalytic reaction [34]. We were thus interested in the mechanism behind the catalytic dinitrogen silylation by the cobalt triphenylphosphine system. Is $\left[\mathrm{Co}\left(\mathrm{PPh}_{3}\right)_{3} \mathrm{~N}_{2}\right]^{-}$the actual catalyst like the bimetallic Lu-Gagliardi complex or merely a pre-catalyst which undergoes a transformation into the catalytically active species through reaction with chlorosilane? To answer this question we started our investigations by studying the performance of the in-situ formed $\left[\mathrm{Co}\left(\mathrm{PPh}_{3}\right)_{3} \mathrm{~N}_{2}\right]^{-}$anion in the catalytic silylation of dinitrogen.

Treating a $0.0025 \mathrm{M}$ solution of $\mathrm{CoH}\left(\mathrm{PPh}_{3}\right)_{3} \mathrm{~N}_{2}$ in THF with 180 equivalents of $\mathrm{Na}$ and 190 equivalents of $\mathrm{Me}_{3} \mathrm{SiCl}$ led to the formation of $6.7 \pm 1.0$ equivalents (per Co atom) of $\mathrm{N}\left(\mathrm{SiMe}_{3}\right)_{3}$ as evidenced by GC. This corresponded to approximately $12 \%$ yield based on sodium (Table 1 ). The identity of $\mathrm{N}\left(\mathrm{SiMe}_{3}\right)_{3}$ was confirmed with mass spectrometry. Analysis of the ammonia content using indophenol method after saponification of the reaction mixture with $1 \mathrm{~N} \mathrm{H}_{2} \mathrm{SO}_{4}$ was in accord with the GC analysis.

For comparison, we also investigated the behavior of cobalt compounds that do not have a coordinated dinitrogen molecule. The use of $\mathrm{Co}(\mathrm{acac})_{3}$ led to the substoichiometric formation of $\mathrm{N}\left(\mathrm{SiMe}_{3}\right)_{3}$, while the use of $\mathrm{CoBr}_{2}$ or Co powder did not result in the formation of $\mathrm{N}\left(\mathrm{SiMe}_{3}\right)_{3}$ (Table 1, entries 2-4). The use of cobaltocene led to the formation of $\mathrm{N}\left(\mathrm{SiMe}_{3}\right)_{3}$ in a slightly higher (but comparable) yield to the one obtained with $\mathrm{CoH}\left(\mathrm{PPh}_{3}\right)_{3} \mathrm{~N}_{2}$ (entry 5$) . \mathrm{N}\left(\mathrm{SiMe}_{3}\right)_{3}$ was not formed when no cobalt was present (entry 6). $\mathrm{CoCl}_{2}\left(\mathrm{PPh}_{3}\right)_{2}$ which features the triphenylphosphine ligand had significantly lower activity (entry 7), while $\mathrm{CoCl}\left(\mathrm{PPh}_{3}\right)_{3}$ (which upon two-electron reduction under 
dinitrogen atmosphere could form $\left.\left[\mathrm{Co}\left(\mathrm{PPh}_{3}\right)_{3} \mathrm{~N}_{2}\right]^{-}\right)$was less active than $\mathrm{CoH}\left(\mathrm{PPh}_{3}\right)_{3} \mathrm{~N}_{2}$ (entry 8). The use of diethyl ether as a solvent led to a slightly lower yield of $\mathrm{N}\left(\mathrm{SiMe}_{3}\right)_{3}$, and in benzene no formation of this compound was detected (entries 9,10). No significant changes in yield were measured when the amount of solvent varied (entries 11,12). The use of lithium as the reductant led to a comparable yield, while for potassium no desired product was formed (entries 13,14). Potassium gave good results with other systems [26] and the failure to obtain the desired product with this reductant is likely caused by a very fast reaction of potassium (disappearance of all solids within less than an hour) with all $\mathrm{Me}_{3} \mathrm{SiCl}$ before the catalytically active species could be formed (see below). The use of potassium graphite instead of metallic potassium led to the formation of 3.5 equivalents of $\mathrm{N}\left(\mathrm{SiMe}_{3}\right)_{3}$. The exact reason why $\mathrm{Me}_{3} \mathrm{SiCl}$ is consumed in unproductive reaction with metallic $\mathrm{K}$ at higher rates than with metallic $\mathrm{Li}$ or $\mathrm{Na}$ or $\mathrm{KC}_{8}$ is currently not clear but remains outside of the scope of this work. For an example of a somewhat related low performance of metallic $\mathrm{K}$ compared to $\mathrm{Na}$ and $\mathrm{KC}_{8}$ in reductive coupling of alkyl chlorides see e.g., [36].

Table 1. Screening of catalytic conditions of reductive silylation of $\mathrm{N}_{2}{ }^{\mathrm{a}}$.

\begin{tabular}{|c|c|c|c|c|c|c|}
\hline$\#$ & Catalyst & Solvent & Vol./mL & Reduct. & Yield $/ \%$ b & TON $^{c}$ \\
\hline $1^{\mathrm{d}}$ & $\mathrm{CoH}\left(\mathrm{PPh}_{3}\right)_{3} \mathrm{~N}_{2}$ & $\mathrm{THF}$ & 10 & $\mathrm{Na}$ & $11.7 \pm 1.6$ & $6.7 \pm 1.0$ \\
\hline $2^{e}$ & $\mathrm{Co}(\mathrm{acac})_{3}$ & THF & 10 & $\mathrm{Na}$ & $0.9 \pm 0.6$ & $0.5 \pm 0.4$ \\
\hline $3^{e}$ & $\mathrm{CoBr}_{2}$ & $\mathrm{THF}$ & 10 & $\mathrm{Na}$ & 0 & $\overline{0}$ \\
\hline 4 & $\mathrm{Co}$ & $\mathrm{THF}$ & 10 & $\mathrm{Na}$ & 0 & 0 \\
\hline $5^{f}$ & $\mathrm{Co}(\mathrm{Cp})_{2}$ & $\mathrm{THF}$ & 10 & $\mathrm{Na}$ & $15.9 \pm 3.4$ & $8.3 \pm 2.3$ \\
\hline $6^{\mathrm{e}}$ & - & $\mathrm{THF}$ & 10 & $\mathrm{Na}$ & 0 & 0 \\
\hline $7^{e}$ & $\mathrm{CoCl}_{2}\left(\mathrm{PPh}_{3}\right)_{2}$ & $\mathrm{THF}$ & 10 & $\mathrm{Na}$ & $1.2 \pm 0.6$ & $0.7 \pm 0.3$ \\
\hline $8^{e}$ & $\mathrm{CoCl}\left(\mathrm{PPh}_{3}\right)_{3}$ & $\mathrm{THF}$ & 10 & $\mathrm{Na}$ & $6.1 \pm 1.2$ & $3.7 \pm 0.7$ \\
\hline 9 & $\mathrm{CoH}\left(\mathrm{PPh}_{3}\right)_{3} \mathrm{~N}_{2}$ & $\mathrm{Et}_{2} \mathrm{O}$ & 10 & $\mathrm{Na}$ & 9.1 & 5.8 \\
\hline 10 & $\mathrm{CoH}\left(\mathrm{PPh}_{3}\right)_{3} \mathrm{~N}_{2}$ & $\mathrm{C}_{6} \mathrm{H}_{6}$ & 10 & $\mathrm{Na}$ & 0 & 0 \\
\hline 11 & $\mathrm{CoH}\left(\mathrm{PPh}_{3}\right)_{3} \mathrm{~N}_{2}$ & $\mathrm{THF}$ & 5 & $\mathrm{Na}$ & 10.8 & 6.8 \\
\hline 12 & $\mathrm{CoH}\left(\mathrm{PPh}_{3}\right)_{3} \mathrm{~N}_{2}$ & THF & 20 & $\mathrm{Na}$ & 11.6 & 7.3 \\
\hline 13 & $\mathrm{CoH}\left(\mathrm{PPh}_{3}\right)_{3} \mathrm{~N}_{2}$ & THF & 10 & $\mathrm{Li}$ & 8.7 & 5.5 \\
\hline 14 & $\mathrm{CoH}\left(\mathrm{PPh}_{3}\right)_{3} \mathrm{~N}_{2}$ & THF & 10 & K & 0 & 0 \\
\hline 15 & $\mathrm{CoH}\left(\mathrm{PPh}_{3}\right)_{3} \mathrm{~N}_{2}$ & $\mathrm{THF}$ & 10 & $\mathrm{KC}_{8}$ & 5.8 & 3.5 \\
\hline
\end{tabular}

a Conditions: $0.025 \mathrm{mmol}$ catalyst, $4.5 \mathrm{mmol}$ reductant; $4.72 \mathrm{mmol} \mathrm{Me} 3 \mathrm{SiCl}$, time $=48 \mathrm{~h} . \mathrm{Me}_{3} \mathrm{Si}-\mathrm{SiMe}_{3}$, $\left(\mathrm{Me}_{3} \mathrm{Si}\right)_{2} \mathrm{NH}$ and $\mathrm{Me}_{3} \mathrm{Si}_{-} \mathrm{C}_{4} \mathrm{H}_{8} \mathrm{O}-\mathrm{SiMe}_{3}$ were observed as the main side products; ${ }^{\mathrm{b}}$ Yield was determined with $\mathrm{GC}$, using decane $(10 \mu \mathrm{L})$ as an internal standard, and is based on the maximum theoretical yield of $\left(\mathrm{Me}_{3} \mathrm{Si}\right)_{3} \mathrm{~N}$ $(1.5 \mathrm{mmol}) ;{ }^{\mathrm{c}} \mathrm{TON}$ is the amount of $\left(\mathrm{Me}_{3} \mathrm{Si}\right)_{3} \mathrm{~N}$ formed per cobalt atom; ${ }^{\mathrm{d}}$ average of four runs; ${ }^{\mathrm{e}}$ average of two runs; ${ }^{\mathrm{f}}$ average of three runs.

Overall, $\mathrm{CoH}\left(\mathrm{PPh}_{3}\right)_{3} \mathrm{~N}_{2}$ showed a rather moderate activity, and although it performed better than its non-dinitrogen-containing analogs $\mathrm{CoCl}\left(\mathrm{PPh}_{3}\right)_{3}$ and $\mathrm{CoCl}_{2}\left(\mathrm{PPh}_{3}\right)_{2}$, it was still less effective than cobaltocene. Next, we undertook mechanistic studies of its catalytic activity, and attempted to detect any possible cobalt intermediates in the trimethylsilylation reaction. The time profile of the formation of $\mathrm{N}\left(\mathrm{SiMe}_{3}\right)_{3}$ reveals an induction period of ca. $4 \mathrm{~h}$ followed by a period of moderate activity (ca. $16 \mathrm{~h}$ ) during which all the sodium is consumed (Figure 4). A somewhat shorter $(1 \mathrm{~h})$ induction period was reported by the group of Nishibayashi for the organometallic cobalt systems. This induction period was proposed to account for the formation of catalytically active species that features trimethylsilyl groups directly bound to the cobalt center [34].

We attempted to shed light on the possible initial transformations of $\mathrm{CoH}\left(\mathrm{PPh}_{3}\right)_{3} \mathrm{~N}_{2}$ using IR spectroscopy. Yamamoto et al. reported that the reduction of $\mathrm{CoH}\left(\mathrm{PPh}_{3}\right)_{3} \mathrm{~N}_{2}$ with sodium results in the formation of $\left[\mathrm{Co}\left(\mathrm{PPh}_{3}\right)_{3} \mathrm{~N}_{2}\right] \mathrm{Na}(\mathrm{THF})_{3}$ [31]. Indeed, the addition of five equivalents of $\mathrm{Na}$ to a THF solution of $\mathrm{CoH}\left(\mathrm{PPh}_{3}\right)_{3} \mathrm{~N}_{2}$ resulted in the disappearance of its characteristic $\mathrm{N} \equiv \mathrm{N}$ stretch vibration at $2091 \mathrm{~cm}^{-1}$ and the appearance of a new peak at $1912 \mathrm{~cm}^{-1}$ attributable to $\left[\mathrm{Co}\left(\mathrm{PPh}_{3}\right)_{3} \mathrm{~N}_{2}\right] \mathrm{Na}(\mathrm{THF})_{3}$. When three equivalents of $\mathrm{Me}_{3} \mathrm{SiCl}$ were added to a solution of $\mathrm{CoH}\left(\mathrm{PPh}_{3}\right)_{3} \mathrm{~N}_{2}$ in THF, the disappearance of the IR signal corresponding to the cobalt-dinitrogen complex was observed within $20 \mathrm{~min}$ and no peaks attributable to a reduced $\mathrm{N}_{2}$ moiety could be observed. When the addition 
of $\mathrm{Me}_{3} \mathrm{SiCl}$ was performed in the presence of metallic sodium, the disappearance of the signal of $\mathrm{CoH}\left(\mathrm{PPh}_{3}\right)_{3} \mathrm{~N}_{2}$ was retarded, suggesting a possible concurrent reaction of $\mathrm{Me}_{3} \mathrm{SiCl}$ with sodium. Still, however, it seemed plausible that the attack of $\mathrm{Me}_{3} \mathrm{SiCl}$ on $\left[\mathrm{Co}\left(\mathrm{PPh}_{3}\right)_{3} \mathrm{~N}_{2}\right]^{-}$would lead to the formation of the active catalyst. Therefore, we investigated whether the reaction of pre-formed $\left[\mathrm{Co}\left(\mathrm{PPh}_{3}\right)_{3} \mathrm{~N}_{2}\right] \mathrm{Na}(\mathrm{THF})_{3}$ with six equivalents of trimethylchlorosilane would lead to the formation of $\mathrm{N}\left(\mathrm{SiMe}_{3}\right)_{3}$. GC-MS analysis of this reaction mixture did not reveal the formation of either $\mathrm{N}\left(\mathrm{SiMe}_{3}\right)_{3}$ or any organic compound containing an $\mathrm{N}-\mathrm{SiMe}_{3}$ moiety. The subsequent addition of 180 equivalents of sodium and $\mathrm{Me}_{3} \mathrm{SiCl}$ to the reaction mixture resulted in the formation of $\mathrm{N}\left(\mathrm{SiMe}_{3}\right)_{3}$, albeit an induction period still was observed.

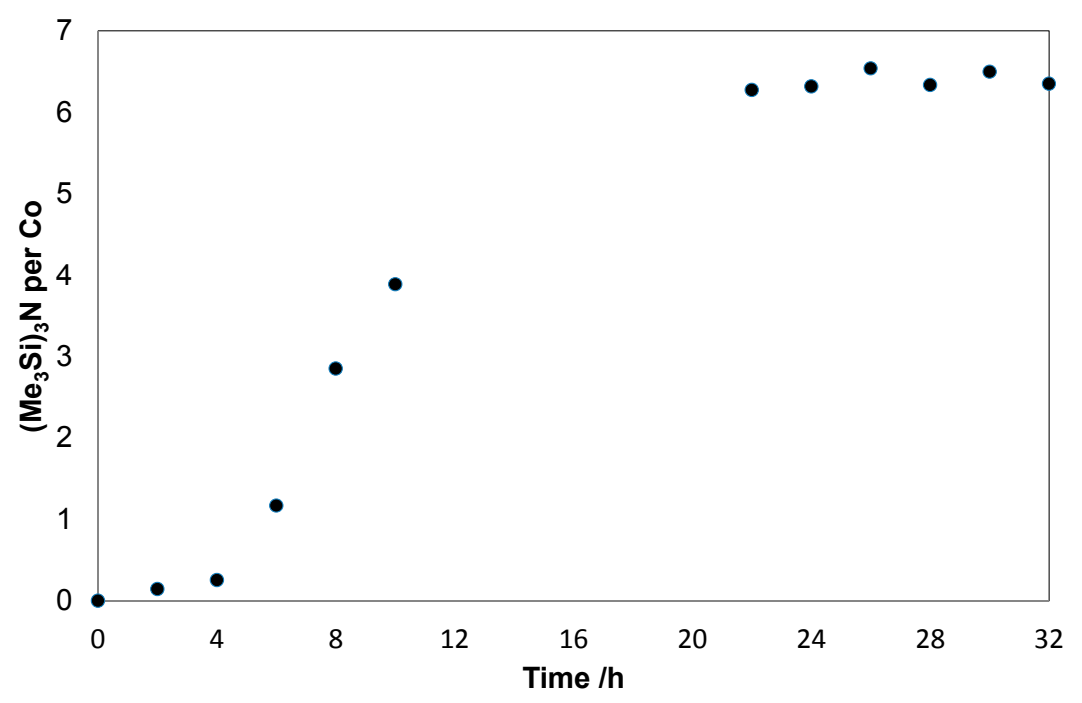

Figure 4. Formation of $\left(\mathrm{Me}_{3} \mathrm{Si}\right)_{3} \mathrm{~N}$ during $\mathrm{N}_{2}$ reduction catalyzed by $\mathrm{CoH}\left(\mathrm{PPh}_{3}\right)_{3} \mathrm{~N}_{2}$.

Since in the first several hours of reaction no formation of $\mathrm{N}\left(\mathrm{SiMe}_{3}\right)_{3}$ is observed, and the stoichiometric reaction of $\mathrm{Me}_{3} \mathrm{SiCl}$ with $\left[\mathrm{Co}\left(\mathrm{PPh}_{3}\right)_{3} \mathrm{~N}_{2}\right]^{-}$does not lead to the formation of $\mathrm{N}-\mathrm{Si}$ bonds, it seemed rather unlikely that the catalytic reaction proceeds on $\mathrm{CoH}\left(\mathrm{PPh}_{3}\right)_{3} \mathrm{~N}_{2}$ $\left(\right.$ or $\left.\left[\mathrm{Co}\left(\mathrm{PPh}_{3}\right)_{3} \mathrm{~N}_{2}\right] \mathrm{Na}(\mathrm{THF})_{3}\right)$. Indeed, IR spectroscopy analysis of an aliquot of a catalytically active mixture taken after $8 \mathrm{~h}$ of reaction revealed no peaks that could be assigned to any $\mathrm{Co}-\mathrm{N}_{2}$ species. This suggests that after the induction period, virtually all $\mathrm{CoH}\left(\mathrm{PPh}_{3}\right)_{3} \mathrm{~N}_{2}$ is decomposed and the bulk of the cobalt is not coordinated with a terminally bound $\mathrm{N}_{2}$.

The majority of the coordination compounds of cobalt are paramagnetic, therefore we used EPR spectroscopy to probe the catalytic reaction mixture. Investigation of the reaction mixture after $3.5 \mathrm{~h}$, i.e., before the onset of the formation of $\mathrm{N}\left(\mathrm{SiMe}_{3}\right)_{3}$, revealed the presence of a strong signal (Figure 5, red line) with clearly visible hyperfine couplings with the cobalt center and a very strong and broad signal spanning through the whole measurement window. Its spectral features $\left(g_{\mathrm{x}}=2.13 ; g_{\mathrm{y}}=2.12\right.$; $g_{\mathrm{z}}=2.02 ; A_{\mathrm{x}}=215 ; A_{\mathrm{y}}=195 ; A_{\mathrm{z}}=180 \mathrm{MHz}$ ) are indicative of a low-spin cobalt(II) species $[35,37,38]$. This species corresponded to approximately $8 \%$ of the total cobalt concentration. The amount of paramagnetic material was calculated from double integrals of the EPR signal of the catalytic reaction mixture and of a solution of Cobalt(II) meso-tetraphenylporphine used as the external standard (see Figure $\mathrm{S} 1 \mathrm{in}$ the supplementary materials). An aliquot from the reaction mixture taken after $48 \mathrm{~h}$ revealed the presence of the same paramagnetic species (with less resolved hyperfine structure, due to the lack of formation of good glass upon freezing) corresponding to approximately $5 \%$ of the total cobalt concentration (Figure 5, blue line). These data suggest that during the reaction of the $\mathrm{CoH}\left(\mathrm{PPh}_{3}\right)_{3} \mathrm{~N}_{2}$ with $\mathrm{Me}_{3} \mathrm{SiCl}$ in $\mathrm{THF}$, a small amount of paramagnetic cobalt(II) species is formed which is not a catalytic intermediate in the $\mathrm{N}_{2}$ fixation reaction. This species can be formed, e.g., by a transfer of a chloro radical from $\mathrm{Me}_{3} \mathrm{SiCl}$ to the cobalt(I) center, or by the attack of the trimethylsilyl 
radical formed after a one-electron reduction of $\mathrm{Me}_{3} \mathrm{SiCl}$. Formation of other cobalt species which could not be easily identified either using IR or EPR spectroscopy cannot be excluded; however, the reduction of the pre-catalyst to metallic cobalt has not been observed during the reaction.

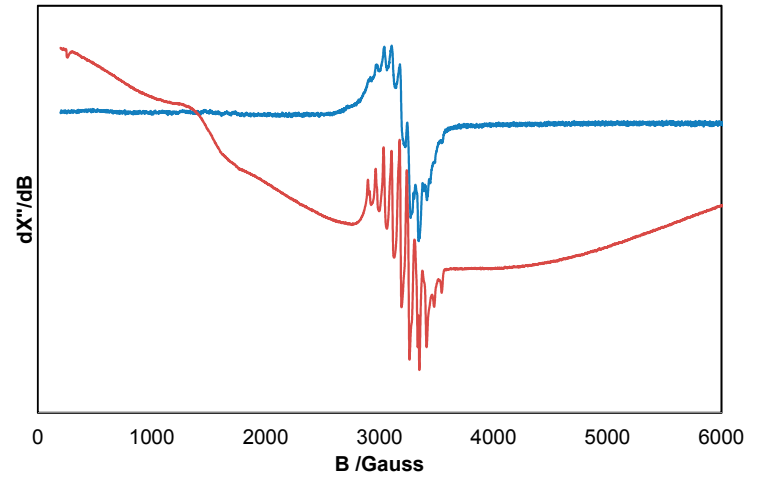

(a)

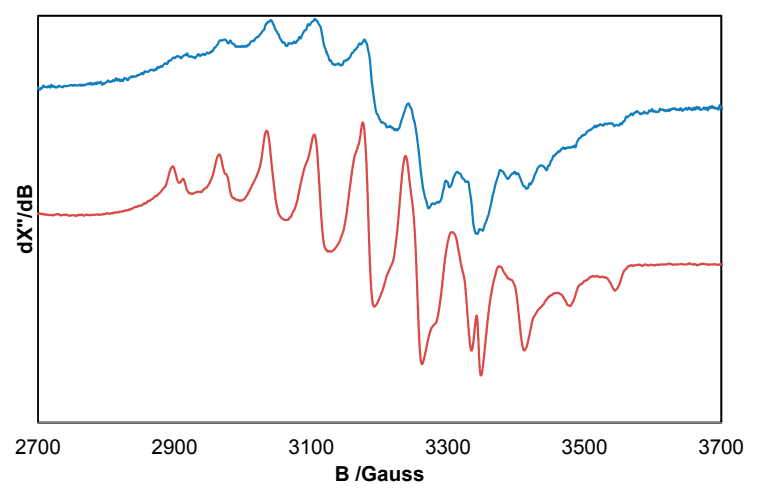

(b)

Figure 5. (a) X-band EPR spectra of the catalytic reaction mixture recorded at $20 \mathrm{~K}$ before the onset (red) and after reaching plateau (blue) of the formation of $\mathrm{N}\left(\mathrm{SiMe}_{3}\right)_{3}$. Frequency $=9.366 \mathrm{GHz}$, modulation amplitude: 4 Gauss, attenuation: $20 \mathrm{~dB}$; (b) Selected part of the spectrum showing the hyperfine couplings of the cobalt(II) species.

Monitoring of the catalytic reaction with ${ }^{31} \mathrm{P}$ NMR did not reveal any substantial signal of triphenylphosphine during the incubation period, and only after two days the signal at $-6.5 \mathrm{ppm}$ corresponding to free triphenylphosphine was observed, constituting less than $10 \%$ of the initial amount of $\mathrm{CoH}\left(\mathrm{PPh}_{3}\right)_{3} \mathrm{~N}_{2}$ (triphenylphosphine oxide added after the reaction stopped was used as an internal standard). This points to the possibility that triphenylphosphine remains bound to cobalt during catalysis; however, a fast exchange of triphenylphosphines on the cobalt center can also account for the lack of NMR signal.

To investigate whether cobalt nanoparticles are the active species, we analyzed the supernatant of the reaction mixture for the presence of nanoparticles using dynamic light scattering (DLS) after the formation of $\mathrm{N}\left(\mathrm{SiMe}_{3}\right)_{3}$ reached plateau. Measurements of the clear, brown solution obtained after sedimentation of the insoluble material formed during the catalytic reaction revealed a bimodal distribution of particles with an average size of 20 and $100 \mathrm{~nm}$ (see Figures S2 and S3 in the supplementary materials). This solution was, however, no longer active in the silylation of $\mathrm{N}_{2}$ when additional sodium and $\mathrm{Me}_{3} \mathrm{SiCl}$ were added. This suggests that even if cobalt nanoparticles are formed, they are an unlikely catalyst for the title reaction.

From the above results it is clear that neither $\mathrm{CoH}\left(\mathrm{PPh}_{3}\right)_{3} \mathrm{~N}_{2}$ nor its reduction product [Co $\left.\left(\mathrm{PPh}_{3}\right)_{3} \mathrm{~N}_{2}\right] \mathrm{Na}(\mathrm{THF})_{3}$ activate $\mathrm{N}_{2}$ towards the formation of $\mathrm{N}-\mathrm{Si}$ bonds. Dinitrogen complexes of cobalt(II) are known [39]; however, it is unlikely that the observed paramagnetic complex is the active species given that it is already present in the reaction mixture before the onset of N(TMS) 3 formation is reached. It is possible that this species is being transformed into the actual catalyst during the incubation period. Since good molecular catalysts for the silylation of dinitrogen can reach over 200 turnovers [25,33], it is plausible that the actual very active catalyst is present only in minute amounts, which prevents its spectroscopic characterization. Based on the work of Nishibayashi, Yoshizawa and co-workers, an in-situ formed metallosilane species [28,34] can be responsible for the catalytic activity of $\mathrm{CoH}\left(\mathrm{PPh}_{3}\right)_{3} \mathrm{~N}_{2}$.

\section{Materials and Methods}

All manipulations were performed using Schlenk techniques under nitrogen or in a nitrogen-filled glovebox. $\mathrm{CoH}\left(\mathrm{PPh}_{3}\right)_{3} \mathrm{~N}_{2}$ was synthesized from $\mathrm{Co}(\mathrm{acac})_{3}(99.99 \%$ trace metal basis, Sigma-Aldrich, 
(St. Louis, MO, USA) (acac = acetylacetonato) as reported previously [40]. $\mathrm{CoCl}\left(\mathrm{PPh}_{3}\right)_{3}$ [41] and $\mathrm{CoCl}_{2}\left(\mathrm{PPh}_{3}\right)_{2}$ [42] were synthesized according to published procedures. THF and $\mathrm{Et}_{2} \mathrm{O}$ were distilled from sodium wire/benzoquinone, benzene and pentane was distilled from sodium wire. $\mathrm{Me}_{3} \mathrm{SiCl}(99 \%$, purified by redestillation) was degassed using freeze-pump-thaw method (three cycles) and stored under nitrogen. Solvents used for catalytic runs were degassed using freeze-pump-thaw method (three cycles) immediately before use. GC measurements were performed on a Shimadzu GC-17A Gas Chromatograph (Shimadzu Corporation, Kyoto, Japan) with a Supelco SPB-1 fused silica capillary column. X-band EPR measurements were performed on a Bruker EMX spectrometer equipped with a He temperature control cryostat system (Oxford Instruments, Tubney Woods, UK). DLS measurements were performed on an ALV/LSE 5003 electronics and multiple Tau digital correlator (ALV-Laser Vertriebsgesellschaft m-b.H, Langen, Germany).

General procedure for catalytic silylation of dinitrogen: $320 \mathrm{mg}$ of sodium $(30 \%-35 \%$ in mineral oil, $4.5 \mathrm{mmol}$ ) was placed in a $100 \mathrm{~mL}$ Schlenk flask equipped with a glass stirring bar. Sodium was washed three times with $5 \mathrm{~mL}$ of pentane and a $22 \mathrm{mg}(0.025 \mathrm{mmol})$ amount of $\mathrm{CoH}\left(\mathrm{PPh}_{3}\right)_{3} \mathrm{~N}_{2}$ was added followed by $10 \mathrm{~mL}$ of THF. The solution was vigorously stirred and $0.6 \mathrm{~mL}(4.7 \mathrm{mmol})$ of $\mathrm{Me}_{3} \mathrm{SiCl}$ was added with syringe. The initially orange-brown mixture turned gray/black after several hours of stirring. After $48 \mathrm{~h}, 10 \mu \mathrm{L}$ of decane as an internal standard was added with a micropipette, and the mixture was centrifuged giving a purple precipitate and green-brown supernatant which was used for analysis of the amount of fixed nitrogen.

\section{Conclusions}

The cobalt-dinitrogen complex $\mathrm{CoH}\left(\mathrm{PPh}_{3}\right)_{3} \mathrm{~N}_{2}$ is a pre-catalyst in the reductive silylation of the dinitrogen reaction. This complex itself does not mediate the formation of $\mathrm{N}-\mathrm{Si}$ bonds; however, under the applied catalytic conditions it transforms to the active species after approximately $4 \mathrm{~h}$. Spectroscopic analysis of the reaction mixture did not reveal the presence of a resting state with a terminally bound $\mathrm{N}_{2}$, and the nanoparticles formed during the course of the reaction are not catalytically active. It is therefore likely that in-situ formed homogeneous cobaltosilane species proposed by Nishibayashi, Yoshiawa and co-workers are responsible for the catalytic activity. Further studies should aim at an unambiguous determination of the structure of the catalytically active species generated from this mononuclear cobalt precursor.

Supplementary Materials: The following are available online at www.mdpi.com/2304-6740/4/3/21/s1, Figure S1. Double integrals of the EPR signal of a $1.28 \mathrm{mM}$ THF solution of cobalt (II) meso-tetraphenylporphine, and of the catalytic reaction mixture measured after 3.5 and $48 \mathrm{~h}$. Figure S2. DLS normalized intensity correlation function. Figure S3. Size distribution of nanoparticles measured with DLS.

Acknowledgments: We thank the Netherlands Organization for Scientific Research (NWO-CW, VENI grant 722.013.002) for funding, Mr. Christophe Rebreyend for measuring the EPR spectra, Dr. Saeed Raoufmoghaddam for measuring DLS, and Prof. Dr. Joost N. H. Reek for his constant encouragement and support.

Conflicts of Interest: The author declares no conflict of interest.

\section{Abbreviations}

The following abbreviations are used in this manuscript:

acac acetylacetonato

DLS dynamic light scattering

EPR electron paramagnetic resonance

GC gas chromatography

IR infrared

MS mass spectrometry

THF Tetrahydrofuran

TON turnover number 


\section{References}

1. Bothe, H.; Schmitz, O.; Yates, M.G.; Newton, W.E. Nitrogen Fixation and Hydrogen Metabolism in Cyanobacteria. Microbiol. Mol. Biol. Rev. 2010, 74, 529-551. [CrossRef] [PubMed]

2. Burgess, B.K.; Lowe, D.J. Mechanism of Molybdenum Nitrogenase. Chem. Rev. 1996, 96, $2983-3012$. [CrossRef] [PubMed]

3. Eady, R.R. Structure-Function Relationships of Alternative Nitrogenases. Chem. Rev. 1996, 96, 3013-3030. [CrossRef] [PubMed]

4. Hoffman, B.M.; Lukoyanov, D.; Yang, Z.-Y.; Dean, D.R.; Seefeldt, L.C. Mechanism of Nitrogen Fixation by Nitrogenase: The Next Stage. Chem. Rev. 2014, 114, 4041-4062. [CrossRef] [PubMed]

5. Hidai, M.; Mizobe, Y. Recent Advances in the Chemistry of Dinitrogen Complexes. Chem. Rev. 1995, 95, 1115-1133. [CrossRef]

6. Bazhenova, T.A.; Shilov, A.E. Nitrogen fixation in solution. Coord. Chem. Rev. 1995, 144, 69-145.

7. Fryzuk, M.D.; Johnson, S.A. The continuing story of dinitrogen activation. Coord. Chem. Rev. 2000, 200-202, 379-409. [CrossRef]

8. MacKay, B.A.; Fryzuk, M.D. Dinitrogen coordination chemistry: On the biomimetic borderlands. Chem. Rev. 2004, 104, 385-401. [CrossRef] [PubMed]

9. Hidai, M.; Mizobe, Y. Research inspired by the chemistry of nitrogenase. Novel metal complexes and their reactivity toward dinitrogen, nitriles, and alkynes. Can. J. Chem. 2005, 83, 358-374. [CrossRef]

10. Hinrichsen, S.; Broda, H.; Gradert, C.; Söncksen, L.; Tuczek, F. Recent developments in synthetic nitrogen fixation. Ann. Rep. Prog. Chem. Sect. A Inorg. Chem. 2012, 108, 17-47. [CrossRef]

11. Van der Ham, C.J.M.; Koper, M.T.M.; Hetterscheid, D.G.H. Challenges in reduction of dinitrogen by proton and electron transfer. Chem. Soc. Rev. 2014, 43, 5183-5191. [CrossRef] [PubMed]

12. Khoenkhoen, N.; de Bruin, B.; Reek, J.N.H.; Dzik, W.I. Reactivity of Dinitrogen Bound to Mid- and Late-Transition-Metal Centers. Eur. J. Inorg. Chem. 2015, 567-598. [CrossRef]

13. Bezdek, M.J.; Chirik, P.J. Expanding Boundaries: $\mathrm{N}_{2}$ Cleavage and Functionalization beyond Early Transition Metals. Angew. Chem. Int. Ed. 2016, 55. [CrossRef] [PubMed]

14. Hazari, N. Homogeneous iron complexes for the conversion of dinitrogen into ammonia and hydrazine. Chem. Soc. Rev. 2010, 39, 4044-4056. [CrossRef] [PubMed]

15. Crossland, J.L.; Tyler, D.R. Iron-dinitrogen coordination chemistry: Dinitrogen activation and reactivity. Coord. Chem. Rev. 2010, 254, 1883-1894. [CrossRef]

16. MacLeod, K.C.; Holland, P.L. Recent developments in the homogeneous reduction of dinitrogen by molybdenum and iron. Nat. Chem. 2013, 5, 559-565.

17. Tanabe, Y.; Nishibayashi, Y. Developing more sustainable processes for ammonia synthesis. Coord. Chem. Rev. 2013, 257, 2551-2564. [CrossRef]

18. Jia, H.-P.; Quadrelli, E.A. Mechanistic aspects of dinitrogen cleavage and hydrogenation to produce ammonia in catalysis and organometallic chemistry: Relevance of metal hydride bonds and dihydrogen. Chem. Soc. Rev. 2014, 43, 547-564. [CrossRef] [PubMed]

19. Yandulov, D.V.; Schrock, R.R. Catalytic reduction of dinitrogen to ammonia at a single molybdenum center. Science 2003, 301, 76-78. [CrossRef] [PubMed]

20. Arashiba, K.; Miyake, Y.; Nishibayashi, Y. A molybdenum complex bearing PNP-type pincer ligands leads to the catalytic reduction of dinitrogen into ammonia. Nat. Chem. 2011, 3, 120-125. [CrossRef] [PubMed]

21. Arashiba, K.; Kinoshita, E.; Kuriyama, S.; Eizawa, A.; Nakajima, K.; Tanaka, H.; Yoshizawa, K.; Nishibayashi, Y. Catalytic Reduction of Dinitrogen to Ammonia by Use of Molybdenum-Nitride Complexes Bearing a Tridentate Triphosphine as Catalysts. J. Am. Chem. Soc. 2015, 137, 5666-5669. [CrossRef] [PubMed]

22. Anderson, J.S.; Rittle, J.; Peters, J.C. Catalytic conversion of nitrogen to ammonia by an iron model complex. Nature 2013, 501, 84-87. [CrossRef] [PubMed]

23. Del Castillo, T.J.; Thompson, N.B.; Peters, J.C. A Synthetic Single-Site Fe Nitrogenase: High Turnover, Freeze-Quench ${ }^{57}$ Fe Mössbauer Data, and a Hydride Resting State. J. Am. Chem. Soc. 2016, 138, 5341-5350. [CrossRef] [PubMed]

24. Shiina, K. Reductive silylation of molecular nitrogen via fixation to tris(trialkylsilyl)amine. J. Am. Chem. Soc. 1972, 94, 9266-9267. [CrossRef] 
25. Komori, K.; Oshita, H.; Mizobe, Y.; Hidai, M. Catalytic conversion of molecular nitrogen into silylamines using molybdenum and tungsten dinitrogen complexes. J. Am. Chem. Soc. 1989, 111, 1939-1940. [CrossRef]

26. Tanaka, H.; Sasada, A.; Kouno, T.; Yuki, M.; Miyake, Y.; Nakanishi, H.; Nishibayashi, Y.; Yoshizawa, K. Molybdenum-Catalyzed Transformation of Molecular Dinitrogen into Silylamine: Experimental and DFT Study on the Remarkable Role of Ferrocenyldiphosphine Ligands. J. Am. Chem. Soc. 2011, 133, 3498-3506. [CrossRef] [PubMed]

27. Liao, Q.; Saffon-Merceron, N.; Mézailles, N. Catalytic Dinitrogen Reduction at the Molybdenum Center Promoted by a Bulky Tetradentate Phosphine Ligand. Angew. Chem. Int. Ed. 2014, 53, 14206-14210. [CrossRef] [PubMed]

28. Yuki, M.; Tanaka, H.; Sasaki, K.; Miyake, Y.; Yoshizawa, K.; Nishibayashi, Y. Iron-catalysed transformation of molecular dinitrogen into silylamine under ambient conditions. Nat. Commun. 2012, 3. [CrossRef] [PubMed]

29. Ung, G.; Peters, J.C. Low Temperature $\mathrm{N}_{2}$ Binding to 2-coordinate $\mathrm{L}_{2} \mathrm{Fe}^{0}$ Enables Reductive Trapping of $\mathrm{L}_{2} \mathrm{FeN}_{2}{ }^{-}$and $\mathrm{NH}_{3}$ Generation. Angew. Chem. Int. Ed. 2015, 54, 532-535.

30. Lloyd, L. Handbook of Industrial Catalysts; Springer: New York, NY, USA, 2011.

31. Yamamoto, A.; Miura, Y.; Ito, T.; Chen, H.; Iri, K.; Ozawa, F. Preparation, X-ray molecular structure determination, and chemical properties of dinitrogen-coordinated cobalt complexes containing triphenylphosphine ligands and alkali metal or magnesium. Protonation of the coordinated dinitrogen to ammonia and hydrazine. Organometallics 1983, 2, 1429-1436. [CrossRef]

32. Betley, T.A.; Peters, J.C. Dinitrogen Chemistry from Trigonally Coordinated Iron and Cobalt Platforms. J. Am. Chem. Soc. 2003, 125, 10782-10783. [CrossRef] [PubMed]

33. Siedschlag, R.B.; Bernales, V.; Vogiatzis, K.D.; Planas, N.; Clouston, L.J.; Bill, E.; Gagliardi, L.; Lu, C.C. Catalytic Silylation of Dinitrogen with a Dicobalt Complex. J. Am. Chem. Soc. 2015, 137, 4638-4641. [CrossRef] [PubMed]

34. Imayoshi, R.; Tanaka, H.; Matsuo, Y.; Yuki, M.; Nakajima, K.; Yoshizawa, K.; Nishibayashi, Y. Cobalt-Catalyzed Transformation of Molecular Dinitrogen into Silylamine under Ambient Reaction Conditions. Chem. Eur. J. 2015, 21, 8905-8909. [CrossRef] [PubMed]

35. Del Castillo, T.J.; Thompson, N.B.; Suess, D.L.M.; Ung, G.; Peters, J. Evaluating Molecular Cobalt Complexes for the Conversion of $\mathrm{N}_{2}$ to $\mathrm{NH}_{3}$. Inorg. Chem. 2015, 54, 9256-9262. [CrossRef] [PubMed]

36. Evans, W.J.; Workman, P.S. Accessing Lanthanide Diiodide Reactivity for Coupling Alkyl Chlorides to Carbonyl Compounds via the $\mathrm{NdI}_{3}$ / Alkali Metal Reduction System. Organometallics 2005, 24, 1989-1991. [CrossRef]

37. Jenkins, D.M.; Di Bilio, A.J.; Allen, M.J.; Betley, T.A.; Peters, J.C. Elucidation of a Low Spin Cobalt(II) System in a Distorted Tetrahedral Geometry. J. Am. Chem. Soc. 2002, 124, 15336-15350. [CrossRef] [PubMed]

38. Korstanje, T.J.; van der Vlugt, J.I.; Elsevier, C.J.; de Bruin, B. Hydrogenation of carboxylic acids with a homogeneous cobalt catalyst. Science 2015, 360, 298-302. [CrossRef] [PubMed]

39. Hojilla Atienza, C.C.; Milsmann, C.; Semproni, S.P.; Turner, Z.R.; Chirik, P.J. Reversible Carbon-Carbon Bond Formation Induced by Oxidation and Reduction at a Redox-Active Cobalt Complex. Inorg. Chem. 2013, 52, 5403-5417. [CrossRef] [PubMed]

40. Yamamoto, A.; Kitazume, S.; Pu, L.S.; Ikeda, S. Synthesis and properties of hydridodinitrogentris (triphenylphosphine)cobalt(I) and the related phosphine-cobalt complexes. J. Am. Chem. Soc. 1971, 93, 371-380. [CrossRef]

41. Aresta, M.; Rossi, M.; Sacco, A. Tetrahedral complexes of cobalt(I). Inorg. Chim. Acta 1969, 3, $227-231$. [CrossRef]

42. Grutters, M.M.P.; Müller, C.; Vogt, D. Highly Selective Cobalt-Catalyzed Hydrovinylation of Styrene. J. Am. Chem. Soc. 2006, 128, 7414-7415. [CrossRef] [PubMed]

(C) 2016 by the author; licensee MDPI, Basel, Switzerland. This article is an open access article distributed under the terms and conditions of the Creative Commons Attribution (CC-BY) license (http:/ / creativecommons.org/licenses/by/4.0/). 